\title{
Action of fentrazamide on protein metabolism and cell division in plants
}

\author{
Sung Jin Lim, Yukari SunOHara and Hiroshi Matsumoto* \\ Doctoral Program in Life Sciences and Bioengineering, Graduate School of Life and \\ Environmental Sciences, University of Tsukuba, Tsukuba, Japan
}

(Received March 5, 2007; Accepted May 7, 2007)

\begin{abstract}
Fentrazamide [4-(2-chlorophenyl)- $N$-cyclohexyl- $N$-ethyl-4,5-dihydro-5-oxo- $1 H$-tetrazole-1-carboxamide] is a new tetrazolinone class herbicide. Fentrazamide at and above $1 \mu \mathrm{M}$ showed marked phytotoxic activity on the growth of early watergrass 15 days after treatment ( $95 \%$ reduction in the total dry weight at $100 \mu \mathrm{M})$, but showed less toxicity to rice. Dry weight of early watergrass and rice was reduced by $50 \%$ with $1.8 \mu \mathrm{M}$ and $95.1 \mu \mathrm{M}$ of fentrazamide, respectively. The pattern of soluble amino acid composition in early watergrass treated with fentrazamide was more similar to that treated with cafenstrole (an inhibitor of fatty acid elongation) than that with mefenacet (an inhibitor of cell division). The inhibition of fatty acid elongation in microsomal fractions of early watergrass by fentrazamide was comparable to that by cafenstrole, but inhibition by fentrazamide was $28-38 \%$ even at the highest concentration $(2 \mu \mathrm{M})$. The cell division of leek roots was not affected by $100 \mu \mathrm{M}$ of fentrazamide. Cycloheximide (an inhibitor of protein biosynthesis) at $10 \mu \mathrm{M}$ showed a marked inhibitory effect on the incorporation of ${ }^{14} \mathrm{C}$-leucine into protein, but fentrazamide showed less inhibitory effect even at $100 \mu \mathrm{M}$; however, fentrazamide at and above $10 \mu \mathrm{M}$ markedly reduced the soluble protein content in early watergrass by $84 \%$, which was much greater than that in rice. These results suggest that fentrazamide has a mode of action which leads to the degradation of protein. CPesticide Science Society of Japan
\end{abstract}

Keywords: fentrazamide, amino acid, very long chain fatty acids (VLCFAs), soluble protein, cell division.

\section{Introduction}

Barnyardgrass (Echinochloa spp.) is one of the most common and troublesome weeds in paddy rice cultivation. For effective barnyardgrass control, herbicides with high efficacy against the weed and good selectivity for rice are required. 1-Phenyl-5(4H)-4-dialkylcarbamoyltetrazolinones exhibited high activity against barnyardgrass in paddy field experiments. ${ }^{1)}$ Fentrazamide, 4-(2-chlorophenyl)- $N$-cyclohexyl- $N$ ethyl-4,5-dihydro-5-oxo-1H-tetrazole-1-carboxamide, has been developed as a rice paddy herbicide for controlling barnyardgrass. In Japan and Korea, this compound is applied at the time of rice transplanting due to its long residual activity. It shows excellent efficacy against barnyardgrass with a wide application range from pre-emergence up to the three-leaf stage with good compatibility with transplanted rice. ${ }^{2,3)}$

Several morphological studies revealed that phytotoxic

\footnotetext{
* To whom correspondence should be addressed.

E-mail: hmatsu@biol.tsukuba.ac.jp

Published online June 30, 2007

(C) Pesticide Science Society of Japan
}

symptoms of fentrazamide were similar to those of oxyacetamides inhibiting cell division. Fentrazamide and mefenacet were shown to inhibit cell division in meristematic areas in Echinochloa spp. based on microscope observations. ${ }^{4)}$ Reductions in the length of young leaves, the number and length of coronal roots, leaf sheaths and leaf blades were also reported. ${ }^{5)}$ Some physiological and biochemical studies reported that fentrazamide inhibited the formation of very long chain fatty acids (VLCFAs), similar to chloroacetamides and chloroacetanilides. The incorporation of $\left[{ }^{14} \mathrm{C}\right]$-oleic acid into sporopollenin, which mainly consists of VLCFA in a green alga Scenedesmus acutus, was sensitive to 0.1 to $1 \mu \mathrm{M}$ of fentrazamide, similarly to chloroacetanilides which inhibit fatty acid modification. ${ }^{6}$ Fentrazamide also caused losses of saturated VLCFAs with the carbon number of 20, 22, and

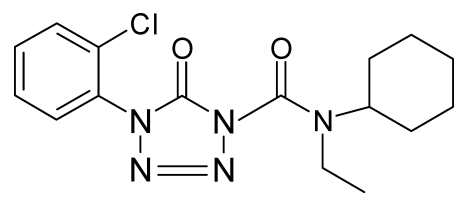

Fig. 1. Chemical structure of the herbicide fentrazimide. 
24. ${ }^{7)}$ Recently, complete inhibition of VLCFA elongases from Arabidopsis thaliana by $100 \mu \mathrm{M}$ fentrazamide treatment was reported. ${ }^{8)}$

Although fentrazamide has been used in paddy fields in Japan since its introduction in the late 1990s, the mode of action at the molecular level has not yet been elucidated. The objective of this study was to determine the mode of action of fentrazamide in grass plants by comparing physiological responses to the relevant herbicides, such as cafenstrole (an inhibitor of VLCFAs) and mefenacet (an inhibitor of cell division), and a protein synthesis inhibitor, cycloheximide.

\section{Materials and Methods}

\section{Chemicals}

Fentrazamide (purity 95\%) was provided by Bayer CropScience, Ltd. (Ibaraki, Japan). All of the other compounds, including cafenstrole, mefenacet, cycloheximide, were purchased from WAKO Pure Chemical Industries, Ltd. (Osaka, Japan).

\section{Plant material}

Seeds of rice (Oryza sativa L. cv. Nipponbare) and early watergrass (Echinochloa oryzicola Vasing.) were washed with tap water and soaked in distilled water at $30^{\circ} \mathrm{C}$ for 2 days. The imbibed seeds were germinated in quarter-strength Kasugai's nutrient solution ${ }^{9)}$ in a growth chamber at $25 / 20^{\circ} \mathrm{C}(12 \mathrm{hr}$ each) for 1 day in the dark. The seedlings were further grown for 7 days to the second leaf stage in the same place at $25 / 20^{\circ} \mathrm{C}\left(12 \mathrm{hr}\right.$ light/dark, ca. $\left.400 \mu \mathrm{Em}^{-2} \mathrm{~s}^{-1}\right)$.

\section{Plant growth response}

The roots of three seedlings of rice and early watergrass were immersed for $24 \mathrm{hr}$ in herbicide solutions $(0.1,1,10$ or 100 $\mu \mathrm{M}$ ) containing $0.1 \%$ acetone and $0.1 \%$ Tween 20 . After washing the roots with distilled water, the plants were transferred to one-strength Kasugai's nutrient solution and grown in the growth chamber. Total fresh weight, shoot and root length, and total dry weight of seedlings were measured 5, 10, and 15 days after treatment.

\section{Amino acid assay}

Amino acids were analyzed according to Demaison et al. ${ }^{10)}$ Leaf and root $(0.5 \mathrm{~g}$ fresh weight) samples from rice and early watergrass treated with 1 or $10 \mu \mathrm{M}$ for $24 \mathrm{hr}$ as described in the growth response experiment were homogenized in $2.5 \mathrm{ml}$ of $15 \mathrm{mM} \mathrm{HCl}$ on ice, and centrifuged at $2000 \times \mathrm{g}$ for $2 \mathrm{~min}$. An aliquot of the supernatant $(0.5 \mathrm{ml})$ was deproteinized with $0.1 \mathrm{ml}$ of $10 \% 5$-sulfosalicylic acid for $15 \mathrm{~min}$ on ice, and centrifuged at $2000 \times g$ for $15 \mathrm{~min}$. Supernatants were adjusted to $\mathrm{pH} 2.2$ with $1 \mathrm{~N} \mathrm{NaOH}$ and subjected to analyses of amino acids using an automatic amino acid analyzer (JLC-300, JEOL Ltd., Tokyo, Japan).

\section{Fatty acid elongation}

Microsome preparation and the experiment of fatty acid elongation were performed according to the method of Böger et al. $^{11)}$ Seeds of rice and early watergrass were germinated in plastic pots containing Kasugai's nutrient solution for 7 days in the dark at $25 / 20^{\circ} \mathrm{C}(12 \mathrm{hr})$. The following operations were carried out at $4^{\circ} \mathrm{C}$. Etiolated rice and early watergrass seedlings ( $4 \mathrm{~g} \mathrm{FW}$ ) were ground in a mortar in $40 \mathrm{ml} \mathrm{N}$-(2-hydroxyethyl)piperazine- $N^{\prime}$-(2-ethanesulfonic acid) (HEPES)/ $\mathrm{KOH}$ buffer $(80 \mathrm{mM}, \mathrm{pH} 7.2)$ containing $320 \mathrm{mM}$ sucrose, $10 \mathrm{mM}$ dithiothreitol (DTT), $2 \mathrm{mM}$ EDTA and $0.3 \mathrm{mM}$ phenylmethanesulfonyl fluoride (PMSF). The homogenate was filtered through eight layers of nylon gauze and the filtrate was centrifuged at $10,000 \times g$ for $20 \mathrm{~min}$. The supernatant was centrifuged at $100,000 \times g$ for 60 min using an ultracentrifuge (Hitachi, Himac CP60E). The microsomal pellet obtained was resuspended in $800 \mu$ l HEPES ( $80 \mathrm{mM}$, pH 7.2) containing $0.1 \%$ Triton X-100, $1 \mathrm{mM}$ DTT, and $1 \mathrm{mM} \mathrm{MgCl}_{2}$. The protein content $(1000-1300 \mu \mathrm{g} / \mathrm{ml})$ of the suspension was determined according to Bradford. ${ }^{12)}$ For elongase inhibition assays, the microsomal protein solution obtained was used as the enzyme preparation $(600 \mu \mathrm{g} / \mathrm{ml})$.

In a final volume of $51 \mu \mathrm{l}$, the assay solution included $25 \mu \mathrm{l}$ microsomal protein preparations, $1 \mu \mathrm{l}$ of $0.1,1,10$, and $100 \mu \mathrm{M}$ fentrazamide dissolved in acetone, $10 \mu \mathrm{l}$ cofactor mixture $(5 \mu \mathrm{l}$ of $2 \mathrm{mM} \mathrm{NADPH}+5 \mu \mathrm{l}$ of $2 \mathrm{mM}$ NADH), $5 \mu \mathrm{l}$ of $250 \mu \mathrm{M}$ C18:0-CoA (stearyl-CoA), and $10 \mu \mathrm{l}$ of $100 \mu \mathrm{M}\left[2-{ }^{14} \mathrm{C}\right]-\mathrm{mal}-$ onyl-CoA. The mixture of the microsomal fraction and herbicide was incubated at $30^{\circ} \mathrm{C}$ for $10 \mathrm{~min}$ before adding the other constituents. One microliter of acetone was used as a control. The reaction was started by adding ${ }^{14} \mathrm{C}$-malonyl-CoA, maintaining for $20 \mathrm{~min}$ at $30^{\circ} \mathrm{C}$ and terminated by $25 \mu \mathrm{l}$ of $60 \% \mathrm{KOH}$.

The elongation products of the in vitro assay were saponified for $30 \mathrm{~min}$ at $80^{\circ} \mathrm{C}$ and acidified with $175 \mu \mathrm{l}$ of $6 \% \mathrm{HCl}$. The labeled fatty acids (C20:0) were extracted with $700 \mu \mathrm{l}$ of a mixture of acetone $/ n$-hexane $(4: 3, \mathrm{v} / \mathrm{v})$. To remove non-reacted water-soluble $\left[{ }^{14} \mathrm{C}\right]$-malonate from the organic phase, the layer was washed with $100 \mu \mathrm{l}$ of $6 \% \mathrm{HCl}$ and the radioactivity of an aliquot was measured. The label incorporation was determined by liquid scintillation counting, measuring the inhibition of stearyl-CoA conversion to VLCFAs. No ATP was included in the assay since it reduced the elongation rate. ${ }^{13)}$ In untreated controls, the incorporation of radioactivity was similar between rice and early watergrass.

\section{Cell division}

Leek (Allium porrum L. cv. Kujoehoso) seeds were germinated for 3 days in a Petri dish containing 1, 10 or $100 \mu \mathrm{M}$ fentrazamide solution. This species was used in the assay due to its characteristic of having large cells. Treated root tips were collected and fixed in $45 \%$ acetic acid for at least $20 \mathrm{~min}$. They were then hydrolyzed in $3 \% \mathrm{HCl}\left(60^{\circ} \mathrm{C}\right)$ for 20-30 sec, rinsed in distilled water, and stained with $1 \%$ acetocarmin solution. After staining, individual root tips $(1 \mathrm{~mm})$ 
were placed on a microscope slide and squashed. This was accomplished by adding a small drop of $45 \%$ acetic acid, drawing most of the acid off with a tissue, and squashing the root tips with a glass rod. When the root tip was well squashed, a little more acid was added and the cells spread around gently into a circle about $1 \mathrm{~cm}$ in diameter. The mitotic index (\%) was obtained by scoring for the number of mitotic figures present per population counted.

\section{Protein synthesis}

Protein synthesis was determined according to the method of Matsumoto et al. ${ }^{14)}$ by measuring the absorption and incorporation of ${ }^{14} \mathrm{C}$-leucine into protein. Ten shoot segments $(60 \mathrm{mg}$ FW) after herbicide treatment were put in a glass vial containing $4.9 \mathrm{ml}$ of incubation buffer $(10 \mathrm{mM}$ potassium phosphate buffer $\mathrm{pH} 6.0,1 \%$ of sucrose) in the same way as for the growth response. ${ }^{14} \mathrm{C}$-Leucine $(0.1 \mathrm{ml}, 18.5 \mathrm{kBq})$ was added and the vial was shaken at $60 \mathrm{rpm}, 25^{\circ} \mathrm{C}$. After 1,2 , and $3 \mathrm{hr}$ incubation, the samples were collected and rinsed 3 times with non-labeled leucine $(10 \mu \mathrm{M})$ and distilled water. The incorporation rate was highest with an incubation time of $3 \mathrm{hr}$. The samples were then homogenized with $9 \mathrm{ml}$ of cold $5 \%$ TCA and incubated on ice for $45 \mathrm{~min}$ for protein precipitation. The homogenates were then filtered with a Whatman GF/C glass microfiber filter. The TCA-precipitable protein on the filter was rinsed step by step with 5\% TCA, ethanol, ethanol : diethyl ether $(1: 1, \mathrm{v} / \mathrm{v})$, and diethyl ether. The filter and the filtrate were collected and their radioactivities were determined with a scintillation counter (Beckman LS 5000 TA). The ${ }^{14} \mathrm{C}$-leucine absorption of samples was determined as the total radioactivity of the filter and the filtrate. Cycloheximide $(10 \mu \mathrm{M})$ was used for comparison.

\section{Soluble protein content}

Triplicate fresh tissue samples $(1 \mathrm{~g})$ from the shoots and roots of rice and early watergrass seedlings treated with the herbicide as described in the growth experiment were homogenized in liquid nitrogen. The fine powder obtained was transferred to cold centrifuge tubes, adding $5 \mathrm{ml}$ of $0.05 \mathrm{mM}$ imidazole ( $\mathrm{pH}$ 7.9) buffer containing $0.005 \mathrm{mM}$ DTT. The homogenates were centrifuged for $30 \mathrm{~min}$ at $15,000 \times g$. The supernatants were collected and centrifuged again for $10 \mathrm{~min}$ at $15,000 \times g$, kept on ice and used for the determination of soluble protein contents according to Bradford. ${ }^{12)}$

\section{Statistical analysis}

All statistical analyses were conducted with SPSS 11.0J (SPSS Japan Inc., Hiroo, Tokyo, Japan), and relationships were considered significant when $P<0.05$. Dunnett's test was performed on the difference between control and herbicide treatments. To estimate the effective concentration of herbicides resulting in $50 \%$ reduction of total dry weight growth $\left(\mathrm{GR}_{50}\right)$, the SPSS Probit Analysis procedure was performed using a log-logistic model. ${ }^{15}$ )

\section{Results}

\section{Effect of fentrazamide on plant growth}

Fentrazamide at and above $1 \mu \mathrm{M}$ suppressed shoot elongation of early watergrass (Fig. 2A). In contrast, that of rice was inhibited at and above $10 \mu \mathrm{M}$ (Fig. 2B). Inhibitory effects of fentrazamide on the total dry weight of both species were similar to those on shoot elongation. Growth reduction (GR) determined from dry weight reached $95 \%$ with $100 \mu \mathrm{M}$ fen-
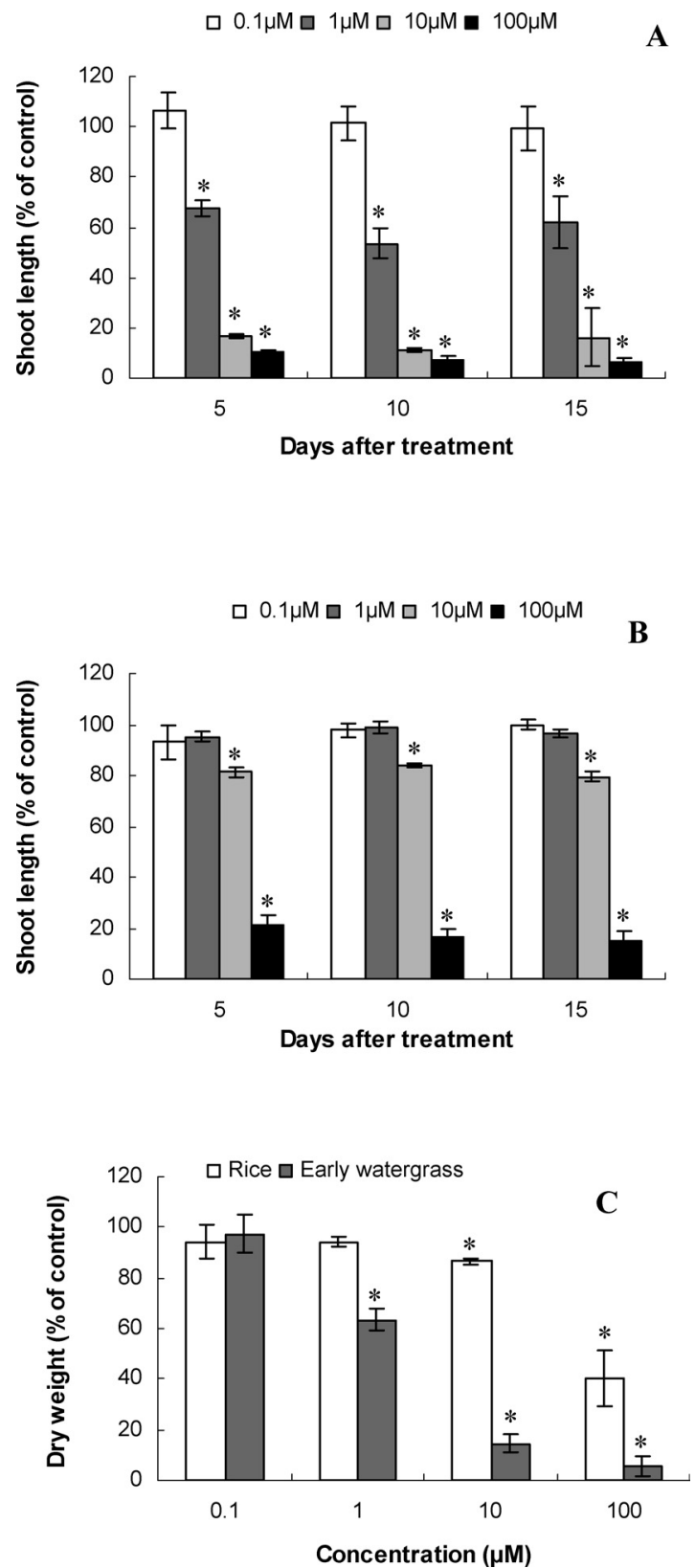

Fig. 2. Effect of fentrazamide on the shoot length of early watergrass (A) and rice (B) seedlings 5, 10, and 15 days after treatment, and on the total dry weight 15 days after treatment (C). Vertical bars represent $\pm \mathrm{SE}$ of the means. * Significantly different from untreated control $(P<0.05)$. 
Table 1. Profiles of increased soluble amino acids in fentrazamide, cafenstrole or mefenacet-treated rice and early watergrass $24 \mathrm{hr}$ after treatment

\begin{tabular}{|c|c|c|c|c|}
\hline \multirow[b]{2}{*}{ Herbicide } & \multicolumn{2}{|c|}{ Early watergrass } & \multicolumn{2}{|c|}{ Rice } \\
\hline & $\begin{array}{c}\text { Shoot } \\
\text { (log \% of control) }\end{array}$ & $\begin{array}{c}\text { Root } \\
(\log \% \text { of control) }\end{array}$ & $\begin{array}{c}\text { Root } \\
\text { (log \% of control) }\end{array}$ & $\begin{array}{c}\text { Shoot } \\
\text { (log \% of control) }\end{array}$ \\
\hline Fentrazamide & Proline $(3.54)^{a)}$ & Histidine $(3.37)^{a)}$ & Asparagine $(2.51)^{a)}$ & Asparagine $(2.58)^{a)}$ \\
\hline \multirow[t]{2}{*}{$10 \mu \mathrm{M}$} & Arginine (3.25) & Ornithine (3.08) & Aspartic acid (2.17) & Glutamine $(2.50)^{a)}$ \\
\hline & Glutamic acid (3.22) & Sarcosine (2.89) & Ornithine $(2.14)^{a)}$ & Aminoisobutyric acid (2.27) \\
\hline Cafenstrole & Proline $(3.38)^{a)}$ & Asparagine (3.01) & Asparagine $(2.85)^{a)}$ & Sarcosine (2.65) \\
\hline \multirow[t]{2}{*}{$10 \mu \mathrm{M}$} & Glutamine (3.27) & Glutamine (2.99) & Ornithine $(2.74)^{a)}$ & Arginine (2.59) \\
\hline & Serine $(2.91)$ & Histidine $\left.(2.97)^{a}\right)$ & Arginine (2.48) & Glutamine $(2.49)^{a)}$ \\
\hline Mefenacet & Glutamine (2.89) & Asparagine (2.82) & Asparagine $\left.(2.25)^{a}\right)$ & Asparagine $(2.47)^{a)}$ \\
\hline \multirow[t]{2}{*}{$10 \mu \mathrm{M}$} & Glycine (2.69) & Glutamine (2.71) & Ornithine $(2.10)^{a)}$ & Glutamine $(2.30)^{a)}$ \\
\hline & Asparagine (2.67) & Aminoadipic acid (2.53) & Sarcosine (2.09) & Proline (2.23) \\
\hline
\end{tabular}

a) Amino acid common to fentrazamide-treated shoots or roots of each species.

trazamide in early watergrass whereas only $60 \%$ in rice (Fig. $2 \mathrm{C}$ ), and the $\mathrm{GR}_{50}$ values were 1.8 and $95.1 \mu \mathrm{M}$ for early watergrass and rice, respectively. Root elongation and total fresh weight were also suppressed in a similar manner to shoot elongation and total dry weight, and the treated plants did not develop new roots (data not shown). Furthermore, in early watergrass, chlorosis was observed 5 days after treatment, except with $0.1 \mu \mathrm{M}$, and necrosis was observed 10 days after treatment at and above $1 \mu \mathrm{M}$. In rice, necrosis was observed 10 days after treatment with $100 \mu \mathrm{M}$. These results indicate that the herbicide has moderate selectivity between species and that early watergrass is more susceptible to fentrazamide than rice.

2. Effect of fentrazamide, cafenstrole and mefenacet on composition of soluble amino acids

To compare the effects of herbicides on amino acid composition, the roots of early watergrass and rice were treated with fentrazamide, cafenstrole (an inhibitor of fatty acid elongation) or mefenacet (an inhibitor of cell division). In early watergrass, fentrazamide caused the greatest increase of proline and histidine contents in shoots and roots, respectively, and these amino acids also increased greatly by cafenstrole but not by mefenacet (Table 1). In rice, fentrazamide caused the greatest increase in aspargine content in both shoots and roots, and this was also observed in shoots exposed to cafenstrole, and in both shoots and roots exposed to mefenacet; however, rice showed much smaller changes in the composition of soluble amino acids after treatment with herbicides than early watergrass. These results indicate that the effect of fentrazamide on soluble amino acid composition in early watergrass is similar to that of cafenstrole rather than mefenacet.
3. Effect of fentrazamide and cafenstrole on fatty acid elongation

The inhibition of fatty acid elongation in microsomal fractions from rice and early watergrass increased with increasing concentrations of fentrazamide and cafenstrole (Fig. 3). In early watergrass, both fentrazamide and cafenstrole inhibited fatty acid elongation at and above $0.2 \mu \mathrm{M}$. In rice, fentrazamide showed a similar profile of inhibition to that in early watergrass; however, even at the highest concentration of fentrazamide tested $(2 \mu \mathrm{M}), 72$ and $65 \%$ of the activity remained in early watergrass and rice, respectively.

\section{Effect of fentrazamide on cell division}

Inhibition of the mitotic index determined 3 days after germination in leek roots gradually increased with increasing concentrations of fentrazamide but the value was not significantly different between the control and any fentrazamide treatments (Fig. 4).

\section{Effect of fentrazamide on protein biosynthesis}

To investigate the effect of fentrazamide on protein synthesis, the incorporation of ${ }^{14} \mathrm{C}$-leucine into protein was examined. In early watergrass, significant inhibition by fentrazamide was observed at 10 and $100 \mu \mathrm{M}$. However, the inhibition of protein biosynthesis in early watergrass and rice by cycloheximide (a known inhibitor of protein biosynthesis) was much greater than that by fentrazamide (Fig. 5).

\section{Effect of fentrazamide on soluble protein}

The soluble protein content in rice and early watergrass decreased with increasing concentrations of fentrazamide (Fig. 6 ). In early watergrass, the significant reduction of soluble 

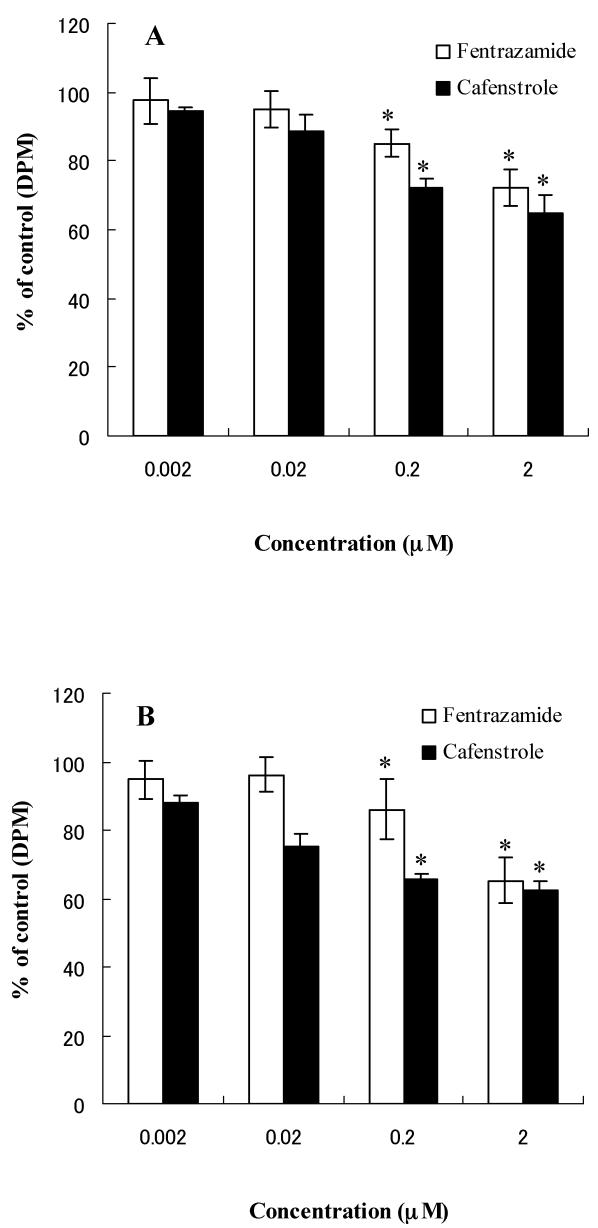

Fig. 3. Effect of fentrazamide and cafenstrole on fatty acid elongation in early watergrass (A) and rice (B) microsomes. Vertical bars represent $\pm \mathrm{SE}$ of the means. * Significantly different from untreated control $(P<0.05)$.

protein contents by fentrazamide was observed at and above 1 and $0.1 \mu \mathrm{M}$ in shoots and roots, respectively, whereas in rice at 10 and $100 \mu \mathrm{M}$. The level of the reduction reached $84-86 \%$ at the highest concentration of the herbicide tested in early watergrass, which was much greater than that in rice (44$51 \%)$.

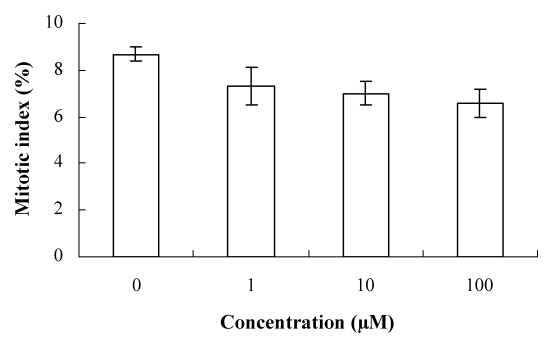

Fig. 4. Effect of fentrazamide on cell division in leek roots. Vertical bars represent \pm SE of the means. Mitotic index was determined 3 days after germination in the herbicide solution.

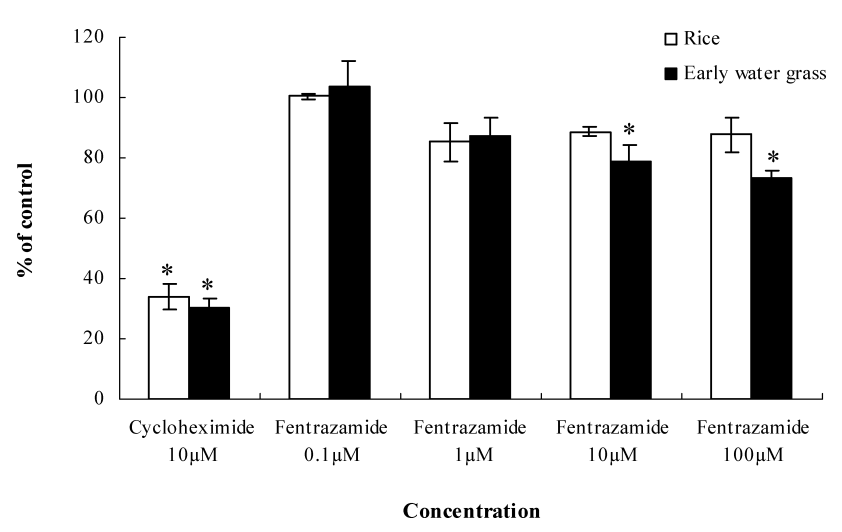

Fig. 5. Effect of fentrazamide on protein biosynthesis in early watergrass and rice seedlings. Vertical bars represent \pm SE of the means. * Significantly different from untreated control $(P<0.05)$.

\section{Discussion}

The mode of action of fentrazamide has been considered the inhibition of cell division ${ }^{4,5)}$ or fatty acid elongation. ${ }^{6-8)} \mathrm{We}$ examined the change of soluble amino acid composition in fentrazamide, cafenstrole or mefenacet-treated early watergrass and rice, because herbicides with the same mode of action show a similar pattern of changes in amino acid composition. ${ }^{16)}$ From the results of amino acid determination, fentrazamide seems to have a mode of action similar to that of cafenstrole in early watergrass (Table 1), suggesting that this herbicide would inhibit fatty acid elongation; however, the inhibition of fatty acid elongation by fentrazamide in early watergrass required higher concentrations than that for the inhibition of plant growth (Fig. 3). Moreover, the inhibition of cell division by this herbicide could not be observed in leek cells (Fig. 4); therefore, it is likely that fatty acid elongation and cell division are not the primary target site of fentrazamide in early watergrass. We focused on the change of soluble amino acid composition and examined if it was the result of the inhibition of protein biosynthesis or the reduction of solu-

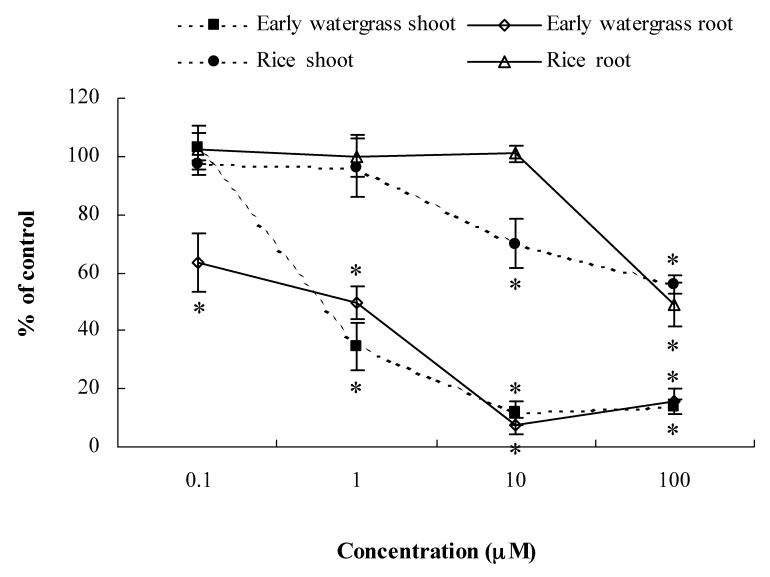

Fig. 6. Effect of fentrazamide on soluble protein content in early watergrass and rice seedlings. Vertical bars represent \pm SE of the means. * Significantly different from untreated control $(P<0.05)$. 
ble protein contents. The lower level of protein biosynthesis inhibition by fentrazamide than by cycloheximide (Fig. 5) suggests that the target site of fentrazamide is other than protein biosynthesis. On the other hand, the reduction levels of soluble protein contents in shoots and roots of early watergrass at and above $1 \mu \mathrm{M}$ fentrazamide were comparable to those of dry weight (Fig. 6), suggesting that protein decomposition might be involved in the mode of action of fentrazamide.

There are several agricultural chemicals which decompose proteins in plant cells. The degradation of both $\alpha$ - and $\beta$ tubulin monomers in rice occurred after $24 \mathrm{hr}$ of oryzalin (a microtubule inhibitor) treatment. ${ }^{17)}$ Pathogenesis-related (PR) protein accumulation after ethephon (an ethylene releaser) treatment in tomato leaf discs was accompanied by a drastic degradation of other cellular proteins. ${ }^{18)}$ The possible involvement of proteinase P69 and perhaps other PR proteins in ethylene-induced acceleration of protein degradation was also suggested. In addition, strong photooxidative conditions promote both the proteolysis of chloroplastic glutathione reductase and degradation of the glutathione pool. ${ }^{19,20)}$ Protein degradation after fentrazamide treatment in rice and early watergrass might be related to those reports; therefore, additional experiments are needed to clarify the involvement of microtubule inhibition, ethylene or active oxygen species in the mode of action of fentrazamide.

\section{Acknowledgment}

The authors thank Bayer CropScience for providing the formulated fentrazamide.

\section{References}

1) T. Goto, S. Ito, A. Yanagi, Y. Watanabe and K. Yasui: Weed Biol. Manag. 2, 18-24 (2002).

2) K. Yasui, T. Goto, H. Miyauchi, A. Yanagi, D. Feucht and H.
Fürsch: Brighton Crop Protection Conference-Weeds, 67-72 (1997).

3) T. Goto, S. Ito, Y. Watanabe, S. Narabu and A. Yanagi (Nihon Bayer Agrochem): Jpn. Kokai Tokkyo Koho JP-A 331153 (1994) (in Japanese).

4) S. Ueno: Noyaku Kenkyu 46, 31-37 (2001) (in Japanese).

5) S. Ito, C. Ueno, T. Goto and K.Yasui: J. Weed Sci. Technol. 45, 81-87 (2000).

6) C. Fedtke, J. Schmalfuß and M. Couderchet: Abstr. 9 th International Congress of Pesticide Chemistry, 4A-011, (1998).

7) B. Matthes, J. Schmalfuß and P. Böger: Z. Naturforsch. 53c, 1004-1011 (1998).

8) S. Trenkamp, W. Martin and K. Tietjen: Proc. Natl. Acad. Sci. USA 101, 11903-11908 (2004).

9) Y. Ohta, K. Yamamoto and M. Deguchi: Jpn. J. Soil Sci. Plant Nutri. 41, 19-26 (1970) (in Japanese).

10) A. M. Demaison, M. H. Marcher and M. Tixier: Phytochemistry 23, 2453-2456 (1984).

11) H. Takahashi, A. Ohki, M. Kanzaki, A. Tanaka, Y. Sato, B. Matthes, P. Böger and K. Wakabayashi: Z. Naturforsch. 56, 781-786 (2001).

12) M. M. Bradford: Anal. Biochem. 72, 248-254 (1976).

13) F. Domergue, S. Chevalier, X. Santarelli, C. Cassagne and R. Lessire: Eur. J. Biochem. 263, 464-470 (1999).

14) H. Matsumoto, S. Nishi and K. Ishizuka: Weed Res. Japan 36, 257-265 (1991)

15) S. S. Seefeldt, J. E. Jensen and E. P. Fuerst: Weed Technol. 9, 218-227 (1995).

16) B. K. Singh and D. L. Shaner: Pestic. Sci. 43, 221-225 (1995).

17) S. Giani, P. Campanoni and D. Breviario: Planta 214, 837-847 (2002).

18) P. Vera and V. Conejero: Plant Physiol. 92, 227-233 (1990).

19) H. R. Lascano, L. D. Gomez, L. M. Casano and V. S. Trippi: Plant Cell Physiol. 40, 683-690 (1999).

20) H. R. Lascano, L. D. Gomez, L. M. Casano and V. S. Trippi: Plant Physiol. Biochem. 36, 321-329 (1998). 